\title{
Induksi Tunas Tembakau (Nicotiana tabacum L) Varietas Kasturi 2 dengan Variasi Konsentrasi BAP secara In Vitro
}

\author{
Author(s): Irma Anindiyati ${ }^{(1)}$; Dyah Nuning Erawati ${ }^{(1) *}$ \\ (1) Jurusan Produksi Pertanian, Politeknik Negeri Jember \\ * Corresponding author: dyah_nuning_e@polije.ac.id
}

Submitted: 02 Okt $2019 \quad$ Revised: 20 Feb $2020 \quad$ Accepted: 25 Feb 2020

\begin{abstract}
ABSTRAK
Tembakau Kasturi 2 merupakan tembakau khas Jember yang memiliki produktifitas relatif tinggi. Perbanyakan secara generatif cenderung menghasilkan bibit yang kurang seragam sehingga dikembangkan dengan teknik kultur jaringan. Dalam kultur jaringan, penambahan zat pengatur tumbuh memberikan pengaruh yang nyata.Penelitian ini bertujuan untuk mengetahui pengaruh penambahan konsentrasi ZPT BAP terhadap induksi tunas tembakau varietas Kasturi 2. Penelitian ini dilaksanakan pada bulan September 2018 hingga Desember 2018 di Laboratorium Kultur Jaringan Politeknik Negeri Jember. Rancangan percobaan yang digunakan adalah Rancangan Acak Lengkap (RAL) Non Faktorial dengan 6 perlakuan yaitu penambahan BAP dengan konsentrasi 0 ppm, 1 ppm, 2 ppm, 3 ppm, 4 ppm, dan 5 ppm. Hasil penelitian menunjukkan bahwa penambahan BAP 2 ppm merupakan konsentrasi terbaik untuk induksi tunas tembakau Kasturi 2 dengan kedinian bertunas 12,17 hari setelah inokulasi, eksplan bertunas $100 \%$, rerata jumlah tunas 47,50 buah per eksplan dan rerata tinggi tunas $1,42 \mathrm{~cm}$.
\end{abstract}

Kata Kunci: BAP; Induksi tunas; Kasturi 2;

Kultur tembakau;

$\begin{array}{ll}\text { Keywords: } & \text { Tobacco var. Kasturi } 2 \text { is typically tobacco of Jember that has high productivity. } \\ \text { BAP; } & \text { Generative propagation tends to produce less resembling seedling. Further development } \\ \text { Kasturi 2; } & \text { by Tissue culture is needed to obtained more seeds. Addition of plant growth promoter } \\ \text { Shoot } & \text { is one of factor that affects the success of in vitro propagation. This research aims to } \\ \text { induction; } & \text { determine the effect of concentration of BAP on shoot induction of Tobacco var. Kasturi } \\ \text { Tobacco tissue } & \text { 2. This research was conducted in September } 2018 \text { to December } 2018 \text { at Tissue Culture } \\ \text { culture; } & \text { Laboratory of State Polytechnic of Jember. This research was using Completely } \\ & \text { Randomized Design non factorial with } 6 \text { treatments. The treatment was addition of BAP } \\ & \text { with concentration of } 0 \text { ppm, } 1 \text { ppm, } 2 \text { ppm, } 3 \text { ppm, } 4 \text { ppm, and } 5 \text { ppm. The results of this } \\ & \text { research showed that the addition of } 2 \text { ppm BAP was the best treatment on shoot } \\ & \text { induction of Tobacco Kasturi } 2 \text { Variety with early budding of } 12,17 \text { day after inoculation, } \\ & \text { 100\% explant produced buds, the average number of bud was } 47,5 \text { per explant and the } \\ & \text { average height of bud was } 1,42 \mathrm{~cm} .\end{array}$




\section{PENDAHULUAN}

Tembakau termasuk tanaman perkebunan yang banyak dibudidayakan di Indonesia. Beberapa daerah di Indonesia menempatkan agribisnis tembakau sebagai andalan penggerak perekonomian daerah dan sumber pendapatan utama bagi petani. Selain itu, tembakau menjadi salah satu penunjang pembangunan nasional berupa devisa negara. Tembakau Kasturi 2 merupakan tembakau yang memiliki keunggulan lebih dari tembakau varietas lainnya seperti produksinya yang tinggi (sekitar 1,75 ton/ha) dan dengan indeks mutu yang relatif tinggi pula yaitu 82,80 (Balai Penelitian Tanaman Pemanis dan Serat, 2014).

Menurut data Badan Pusat Statistik produksi tanaman tembakau mengalami peningkatan dan penurunan pada tahun 2011-2017. Pada tahun 2011 produksi tembakau sebanyak 212.153 ton hingga tahun 2017 hanya mencapai 197.497 ton. Dan volume ekspor lebih rendah daripada volume impor daun tembakau. Volume ekspor pada tahun 2016 sebesar 21.933 ton sedangkan volume impor pada tahun yang sama sebesar 52.482 ton (Direktorat Jenderal Perkebunan, 2017)

Budidaya tanaman tembakau selama ini dilakukan secara konvensional, yaitu pembibitan menggunakan biji. Pembibitan seacara generatif (menggunakan biji) menghasilkan sifat sifat genetik individu yang tidak sama persis dengan induknya. Atas dasar fakta tersebut, proses pembibitan sangat berperan penting untuk mempertahankan kualitas dalam budidaya tanaman tembakau. Upaya yang dapat dilakukan untuk mengatasi hal tersebut adalah dengan penyediaan bibit atau bahan tanam tembakau yang berkualitas tinggi melalui teknik kultur jaringan (in vitro). (Zulkarnain, 2011) menyatakan bahwa teknik kultur jaringan dapat menghasilkan tanaman yang memiliki sifat identik dengan induk, bebas dari penyakit, menghasilkan banyak bibit unggul dalam waktu singkat dan tidak membutuhkan lahan yang luas.

Komposisi media merupakan salah satu faktor yang dapat mempengaruhi keberhasilan perbanyakan secara in vitro. (Zulkarnain, 2011) menyatakan bahwa dalam menerapkan kultur jaringan, aplikasi zat pengatur tumbuh sangat berpengaruh nyata. Sehingga akan sangat sulit jika menerapkan teknik kultur jaringan tanpa melibatkan peran zat pengatur tumbuh didalamnya. ZPT yang sering dimanfaatkan untuk kultur jaringan tembakau adalah jenis auksin dan sitokinin. Sitokinin merupakan senyawa yang mampu meningkatkan pembelahan sel dan mengatur pertumbuhan dan perkembangan tanaman.

Erawati et al. (2018) juga menyatakan bahwa penambahan BAP dengan konsentrasi 2 ppm dapat menginduksi tunas terbanyak yaitu 28,375 tunas, pada konsentrasi 3 ppm BAP dapat menginduksi tunas dengan waktu tercepat yaitu 15,75 HST, penambahan BAP dengan konsentrasi 4 ppm dapat menghasilkan tunas tertinggi yaitu 18,00 $\mathrm{cm}$ pada tembakau White Burley. Penambahan ZPT BAP 4 ppm dan NAA 0 ppm pada kultur jaringan tembakau varietas Prancak 95 menghasilkan 44,75 tunas (Nisak et al., 2012). Pada tembakau varietas Kasturi 2 masih belum ada penelitian yang serupa, sehingga perlu dilakukan pengkajian lebih lanjut untuk mengetahui konsentrasi BAP yang tepat terhadap induksi tunas tembakau varietas Kasturi 2.

\section{BAHAN DAN METODE}

Penelitian ini dilaksanakan pada bulan September 2018 sampai Desember 2018 di Laboratorium Kultur Jaringan Tanaman Politeknik Negeri Jember. Rancangan percobaan yang digunakan adalah Rancangan Acak Lengkap (RAL) Non Faktorial yakni variasi konsentrasi BAP pada media MS, yaitu penambahan 
BAP 0 ppm, 1 ppm, 2 ppm, 3 ppm, 4 ppm, 5 ppm.

Pelaksanaan penelitian :

1. Pembuatan Media Perlakuan

Media perlakuan dibuat dengan menambahkan larutan stok hara makro dan mikro, asam amino, vitamin, gula dan ZPT BAP sesuai perlakuan kemudian ditambahkan agar-agar.

2. Persiapan dan Sterilisasi Eksplan Eksplan yang digunakan berupa daun kedua dan ketiga varietas Kasturi 2 yang berumur 2,5 bulan. Daun tembakau yang akan dijadikan eksplan tersebut dibilas dengan menggunakan air mengalir hingga bersih. Kemudian dicuci dengan menggunakan larutan tween selama 5 menit. Selanjutnya direndam dan digojog dengan menggunakan larutan fungisida $15 \mathrm{~g} / \mathrm{L}$ dan bakterisida $1,5 \mathrm{~mL} / \mathrm{L}$ selama 20 menit. Setelah itu celupkan kedalam larutan alkohol 96\% selama 10 detik dan kemudian dibilas dengan aquades steril. Kemudian direndam dengan larutan klorox 10\% selama 5 menit dan selanjutnya dibilas dengan aquades steril.

3. Inokulasi

Daun tembakau yang sudah disterilkan kemudian dipotong - potong dengan ukuran $1 \mathrm{~cm} 2$ diusahakan setiap sisinya terlukai atau terpotong. Setelah itu eksplan yang sudah dipotong ditanam kedalam media perlakuan. Penanaman atau inokulasi dilakukan didalam Laminar Air Flow Cabinet (LAFC). Setiap botol di isi satu eksplan.

4. Inkubasi dan Pengamatan

Eksplan yang telah ditanam ditata di rak kultur pada ruang inkubasi. Dengan suhu ruang inkubasi yang sama selama 8 minggu. Parameter yang diamati adalah kedinian tunas (hsi), eksplan bertunas (\%), jumlah tunas (buah) dan tinggi tunas $(\mathrm{mm})$.

\section{HASIL DAN PEMBAHASAN}

Tabel 1. Rangkuman Nilai F-hitung pada Induksi Tunas Tembakau (Nicotiana tabacum L.) Varietas Kasturi 2 dengan Variasi Konsentrasi BAP secara In Vitro

\begin{tabular}{|c|c|c|c|c|c|}
\hline \multirow[t]{2}{*}{ No. } & \multirow{2}{*}{$\begin{array}{l}\text { Parameter } \\
\text { Parameters }\end{array}$} & \multirow{2}{*}{$\begin{array}{c}\text { F-Hitung } \\
\text { F-value }\end{array}$} & & \multicolumn{2}{|c|}{$\begin{array}{l}\text { F-Tabel } \\
\text { F-Table }\end{array}$} \\
\hline & & & & $5 \%$ & $1 \%$ \\
\hline 1 & $\begin{array}{l}\text { Kedinian tunas } \\
\text { Early Budding }\end{array}$ & 1872,634 & $* *$ & 2,773 & 4,248 \\
\hline 2 & $\begin{array}{c}\text { Eksplan bertunas } \\
\text { Explant Presenting Bud } \\
2 \text { MSI }\end{array}$ & 3,892 & $*$ & 2,773 & 4,248 \\
\hline & $4 \mathrm{MSI}$ & 5,182 & $* *$ & 2,773 & 4,248 \\
\hline & $6 \mathrm{MSI}$ & 7,517 & $* *$ & 2,773 & 4,248 \\
\hline & $8 \mathrm{MSI}$ & 33,76 & $* *$ & 2,773 & 4,248 \\
\hline 3 & $\begin{array}{l}\text { Jumlah tunas } \\
\text { Number of Bud }\end{array}$ & 11,091 & $* *$ & 2,773 & 4,248 \\
\hline 4 & $\begin{array}{l}\text { Tinggi tunas } \\
\text { Height of Bud }\end{array}$ & 64,139 & $* *$ & 2,773 & 4,248 \\
\hline
\end{tabular}

Keterangan :

* : Berpengaruh nyata (nilai F-Hitung $<$ nilai F-Tabel pada taraf $1 \%$ dan nilai F-Hitung $>$ F-Tabel pada taraf $5 \%)$

** : Berpengaruh sangat nyata (nilai F-Hitung $>$ nilai F-Tabel pada taraf $1 \%$ ) 


\section{Kedinian Tunas (HSI)}

Tunas lebih banyak muncul pada luka bekas sayatan dan juga bagian eksplan yang bersentuhan langsung dengan media. Kedinian tunas ditandai dengan terbentuknya tunas berwarna hijau dan hasil uji beda rata-rata tertera pada Tabel 2 .

Berdasarkan Tabel 2, eksplan yang memberikan respon paling baik dalam membentuk tunas tercepat adalah perlakuan dengan penambahan $1 \mathrm{ppm}$ BAP (P2) dengan rata-rata 10,42 HSI (hari setelah inokulasi). Tetapi tidak berbeda nyata dengan perlakuan P3 (MS + 2 ppm BAP), P4 (MS + 3 ppm BAP) dan P5 (MS + 4 ppm BAP) karena menunjukkan notasi yang sama. Hal tersebut menunjukkan bahwa penambahan zat pengatur BAP pada konsentrasi 1 ppm, 2 ppm, 3 ppm dan 4 ppm akan memberikan kedinian membentuk tunas yang tidak berbeda nyata berkisar 10,42 - 12,17 HSI.

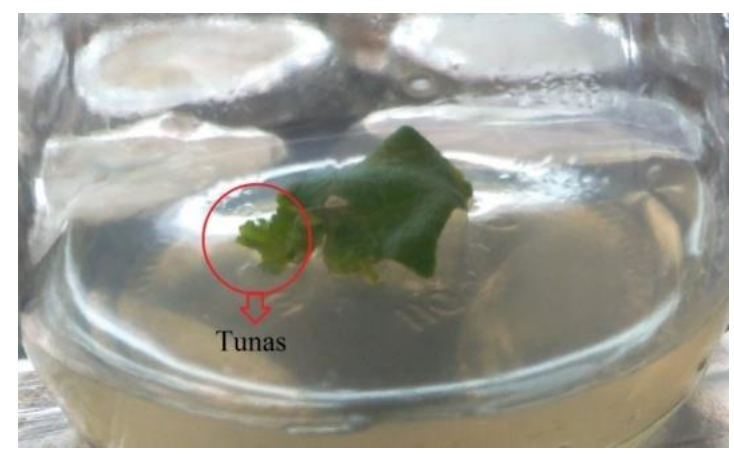

Gambar 1. Eksplan yang Berhasil Menumbuhkan Tunas

Tabel 2. Rerata Kedinian Tunas pada Induksi Tunas Tembakau (Nicotiana tabacum L.) Varietas Kasturi 2 dengan Variasi Konsentrasi BAP secara In Vitro.

\begin{tabular}{|c|c|}
\hline $\begin{array}{l}\text { Perlakuan (BAP) } \\
\text { Treatment (BAP) }\end{array}$ & $\begin{array}{c}\text { Kedinian Tunas (HSI) } \\
\text { Early Budding }\end{array}$ \\
\hline $\mathrm{P} 1$ (MS + 0ppm BAP) & $60,00 \mathrm{c}$ \\
\hline $\mathrm{P} 2$ (MS + 1ppm BAP) & 10,42 \\
\hline $\mathrm{P} 3(\mathrm{MS}+2 \mathrm{ppm} \mathrm{BAP})$ & 12,17 \\
\hline $\mathrm{P} 4$ (MS + 3ppm BAP) & 12,00 \\
\hline $\mathrm{P} 5(\mathrm{MS}+4 \mathrm{ppm} \mathrm{BAP})$ & 11,92 \\
\hline $\mathrm{P} 6$ (MS + 5ppm BAP) & 14,33 \\
\hline
\end{tabular}

Keterangan : Angka yang diikuti huruf yang sama pada satu kolom menunjukkan angka yang berbeda tidak nyata berdasarkan uji DMRT (Duncan's Multiple Range Test)

Note: The numbers followed by same alphabet show insignificant difference based on DMRT (Duncan's Multiple Range Test)

Penambahan zat pengatur tumbuh BAP pada konsentrasi $1-4$ ppm diduga merupakan konsentrasi optimal yang dapat memicu tumbuhnya tunas lebih dini dibandingkan dengan perlakuan yang lain. Eksplan daun tembakau Kasturi 2 yang ditumbuhkan pada media MS tanpa penambahan BAP (P1) menunjukkan kedinian pembentukan tunas yang paling lambat yaitu 60 HSI. Hal tersebut diduga bisa terjadi karena eksplan tidak menerima asupan hormon dari media dan hormon endogen dalam eksplan belum mampu memenuhi kebutuhan hormon untuk memicu tumbuhnya tunas. Sarala and Ravisankar (2013) dalam penelitiannya menyatakan bahwa perlakuan 0 ppm BAP atau perlakuan media MS tanpa pemberian hormon tidak menunjukkan adanya pertumbuhan tunas pada tembakau India.

Pertumbuhan eksplan menjadi salah satu indikator keberhasilan dalam kultur jaringan. Semakin cepat tunas muncul maka akan semakin cepat pula dihasilkan bahan untuk perbanyakan tanaman. (Sultan et al., 2011) menyatakan bahwa media dasar yang ditambah dengan zat pengatur tumbuh membutuhkan waktu minimal 
untuk perbanyakan tunas, sehingga penambahan jenis zat pengatur tumbuh dengan konsetrasi tertentu akan mempengaruhi arah pertumbuhan dari eksplan yang dikulturkan dan akan segera memicu proses diferensiasi menjadi jaringan baru.

\section{Eksplan Bertunas (\%)}

Persentase eksplan bertunas merupakan jumlah eksplan yang mampu menumbuhkan tunas pada setiap perlakuan. Pengamatan parameter eksplan bertunas dilakukan pada setiap 2 minggu sekali yaitu pada 2 MSI, 4 MSI, 6 MSI, dan 8 MSI. Rerata eksplan bertunas tertera pada Tabel 3.

Berdasarkan Tabel 3, perlakuan P2 menunjukkan persentase yang paling tinggi dalam eksplan bertunas yaitu 50\% $70 \%$ pada pengamatan 2 MSI dan 4 MSI tetapi tidak berbeda nyata dengan $\mathrm{P} 3, \mathrm{P} 4$ dan P5 pada minggu ke 2 setelah inokulasi. Hal ini diduga bahwa pada konsentrasi 1 4 ppm mampu menginduksi tunas dengan cepat dibandingkan dengan konsentrasi lainnya. Perlakuan P1 berbeda tidak nyata dengan P5 dan P6, hal ini diduga bahwa pada konsentrasi yang sangat kurang atau lebih akan memperlambat pembentukan tunas pada eksplan tembakau. Pernyataan tersebut didukung oleh Nisak et al. (2012) yang menyatakan bahwa ZPT yang ditambahkan dalam media kultur jaringan, jika dalam konsentrasi yang rendah akan memicu dan mempercepat pertumbuhan tanaman.

Tabel 3. Rerata Eksplan Bertunas pada Induksi Tunas Tembakau (Nicotiana tabacum L.) Varietas Kasturi 2 dengan Variasi Konsentrasi BAP secara In Vitro.

\begin{tabular}{|c|c|c|c|c|c|c|c|c|}
\hline \multirow{3}{*}{$\begin{array}{c}\text { Perlakuan (BAP) } \\
\text { Treatment }(B A P) \\
\text { P1 (MS + } 0 \text { ppm BAP })\end{array}$} & \multicolumn{8}{|c|}{$\begin{array}{c}\text { Eksplan Bertunas (\%) } \\
\text { Explant Precenting Bud (\%) }\end{array}$} \\
\hline & \multicolumn{2}{|c|}{$2 \mathrm{MSI}$} & \multicolumn{2}{|c|}{4 MSI } & \multicolumn{2}{|c|}{$6 \mathrm{MSI}$} & \multicolumn{2}{|c|}{$8 \mathrm{MSI}$} \\
\hline & 0,00 & $\mathrm{a}$ & 0,00 & $\mathrm{a}$ & 0,00 & $\mathrm{a}$ & 0,00 & $\mathrm{a}$ \\
\hline $\mathrm{P} 2$ (MS + 1 ppm BAP) & 50,00 & $\mathrm{c}$ & 70,00 & $\mathrm{c}$ & 85,00 & $\mathrm{~b}$ & 85,00 & $\mathrm{bc}$ \\
\hline $\mathrm{P} 3(\mathrm{MS}+2$ ppm BAP) & 40,00 & $\mathrm{c}$ & 55,00 & $\mathrm{bc}$ & 90,00 & $\mathrm{~b}$ & 100,00 & $\mathrm{c}$ \\
\hline $\mathrm{P} 4$ (MS + 3 ppm BAP) & 35,00 & $\mathrm{bc}$ & 45,00 & $\mathrm{bc}$ & 75,00 & $\mathrm{~b}$ & 100,00 & $\mathrm{c}$ \\
\hline P5 (MS + 4 ppm BAP) & 20,00 & $a b c$ & 40,00 & $\mathrm{bc}$ & 50,00 & $\mathrm{~b}$ & 65,00 & $\mathrm{~b}$ \\
\hline $\mathrm{P} 6(\mathrm{MS}+5 \mathrm{ppm}$ BAP) & 5,00 & $a b$ & 35,00 & $\mathrm{~b}$ & 50,00 & $\mathrm{~b}$ & 80,00 & $\mathrm{bc}$ \\
\hline
\end{tabular}

Keterangan : Angka yang diikuti huruf yang sama pada satu kolom menunjukkan angka yang berbeda tidak nyata berdasarkan uji DMRT (Duncan's Multiple Range Test)

Note: The numbers followed by same alphabet show insignificant difference based on DMRT (Duncan's Multiple Range Test)

Eksplan bertunas pada 6 minggu setelah inokulasi menunjukkan bahwa penambahan zat pengatur tumbuh BAP dalam konsentrasi $1-5$ ppm akan memberikan pengaruh yang tidak berbeda nyata, yaitu 50\% - 90\%. Perlakuan P3 dan P4 mencapai $100 \%$ pada parameter eksplan bertunas pada minggu ke-8 setelah inokulasi, tetapi hal tersebut tidak berbeda nyata dengan perlakuan P2 dan P6.

\section{Jumlah Tunas (buah)}

Pengamatan parameter jumlah tunas dilakukan pada akhir pengamatan (8 MSI). Jumlah tunas yang dihitung adalah tunas yang telah mencapai tinggi minimal $0,5 \mathrm{~cm}$ atau $5 \mathrm{~mm}$. Rerata jumlah tunas yang terbentuk pada setiap perlakuan tertera pada Tabel 4.

Tabel 4 menunjukkan bahwa perlakuan yang menghasilkan rata-rata jumlah tunas yang paling besar adalah $\mathrm{P} 3$ $(\mathrm{MS}+2$ ppm BAP) dengan tunas sebanyak 
47,50 tunas, sehingga dapat diasumsikan bahwa penambahan konsentrasi BAP dalam media mampu memicu eksplan untuk menghasilkan banyak tunas. Sejalan dengan pernyataan tersebut, Erawati et al.
(2018) menyatakan bahwa tunas terbanyak dihasilkan pada eksplan yang media tumbuhnya diberi perlakuan 2 ppm BAP yaitu sebanyak 28,375 tunas.

Tabel 4. Rerata Jumlah Tunas pada Induksi Tunas Tembakau (Nicotiana tabacum L.) Varietas Kasturi 2 dengan Variasi Konsentrasi BAP secara In Vitro.

\begin{tabular}{crc}
\hline $\begin{array}{c}\text { Perlakuan (BAP) } \\
\text { Treatment }(B A P)\end{array}$ & $\begin{array}{c}\text { Jumlah Tunas (buah) } \\
\text { Number of Shoots }\end{array}$ \\
\hline P1 (MS + 0ppm BAP) & 0,00 & a \\
\hline P2 (MS + 1ppm BAP) & 24,75 & $\mathrm{~b}$ \\
\hline P3 (MS + 2ppm BAP) & 47,50 & $\mathrm{c}$ \\
\hline P4 (MS + 3ppm BAP) & 25,00 & $\mathrm{~b}$ \\
\hline P5 (MS + 4ppm BAP) & 25,00 & $\mathrm{~b}$ \\
\hline P6 (MS + 5ppm BAP) & 18,25 & $\mathrm{~b}$ \\
\hline
\end{tabular}

Keterangan : Angka yang diikuti huruf yang sama pada satu kolom menunjukkan angka yang berbeda tidak nyata berdasarkan uji DMRT (Duncan's Multiple Range Test)

Note: The numbers followed by same alphabet show insignificant difference based on DMRT (Duncan's Multiple Range Test)

Perlakuan P1 (tanpa penambahan BAP) tidak tumbuh tunas hingga akhir pengamatan ( $8 \mathrm{MSI})$. Hal tersebut diduga karena pada konsentrasi 0 ppm BAP (perlakuan tanpa penambahan zat pengatur tumbuh BAP), hormon endogen dalam eksplan berada dalam kadar yang kurang memenuhi kebutuhan untuk menunjang tumbuhnya tunas. Tembakau secara alami tidak mampu membentuk tunas pada daun, Tjitrosoepomo (1985) menyatakan bahwa daun merupakan salah satu organ tumbuhan yang memiliki pertumbuhan terbatas dengan hormon pertumbuhan dalam daun yang terbatas pula, sehingga perlu adanya penambahan zat pengatur tumbuh untuk menginduksi tunas pada eksplan yang berasal dari daun. Perlakuan $\mathrm{P} 2$ (MS + 1 ppm BAP) memberikan respon yang berbeda tidak nyata dengan perlakuan $\mathrm{P} 4$ (MS + 3 ppm BAP), P5 (MS + 4 ppm BAP), dan P6 (MS + 5 ppm BAP). Fahmi (2014) menyatakan bahwa respon tanaman terhadap penambahan zat pengatur tumbuh dipengaruhi oleh beberapa faktor diantaranya jenis tanaman, jenis zat pengatur tumbuh, cara aplikasi dan konsentrasi yang diberikan.

Tinggi Tunas (mm)

Penambahan zat pengatur tumbuh pada media akan mempengaruhi ukuran (tinggi) tunas pada eksplan. Menurut Erawati et al. (2018) kontrol genetik pada masing-masing varietas dapat mempengaruhi tingkat regenerasi dan perkembangan organ. Tinggi tunas yang terbentuk menunjukkan bahwa penambahan BAP dengan konsentrasi tertentu dapat memberikan pengaruh yang nyata.

Berdasarkan Tabel 2 rerata tinggi tunas yang paling besar atau yang paling tinggi terdapat pada perlakuan P3 (MS + 2 ppm BAP) yaitu $1,42 \mathrm{~cm}$ yang berbeda nyata dengan perlakuan lainnya. Hal tersebut diduga bahwa dalam media dengan penambahan BAP 2 ppm tersebut merupakan konsentrasi optimal untuk mendukung pertumbuhan tunas. Hasil penelitian yang telah dilakukan oleh (Fathurrahman et al., 2012), memperlihatkan bahwa penambahan BAP 1 ppm dan NAA 0 ppm dapat 
menghasilkan tunas tertinggi yaitu $6,16 \mathrm{~cm}$ pada tanaman tomat, sehingga dengan penambahan BAP tunggal atau tanpa NAA mampu menginduksi sel-sel tanaman untuk berkembang dan terus bertambah ukurannya. Pada perlakuan P2 (MS + 1 ppm BAP), P4 (MS + 3 ppm BAP), P5 (MS + 4 ppm BAP), dan P6 (MS + 5 ppm BAP) menunjukkan hasil yang berbeda tidak nyata dengan rata-rata tinggi tunas $0,8 \mathrm{~cm}$. Penambahan sitokinin pada taraf tertentu akan memacu pembentukan tunas, sehingga sesuai dengan fungsi sitokinin yaitu merangsang pembentukan tunas (Fathurrahman et al., 2012).

Tabel 5. Rerata Tinggi Tunas pada Induksi Tunas Tembakau (Nicotiana tabacum L.) Varietas Kasturi 2 dengan Variasi Konsentrasi BAP secara In Vitro.

\begin{tabular}{|c|c|}
\hline $\begin{array}{l}\text { Perlakuan (BAP) } \\
\text { Treatment (BAP) }\end{array}$ & $\begin{array}{l}\text { Tinggi Tunas }(\mathrm{cm}) \\
\text { Height of } B u d(\mathrm{~cm})\end{array}$ \\
\hline $\mathrm{P} 1(\mathrm{MS}+0 \mathrm{ppm}$ BAP) & $0,00 \quad \mathrm{a}$ \\
\hline $\mathrm{P} 2(\mathrm{MS}+1 \mathrm{ppm}$ BAP) & 0,81 \\
\hline $\mathrm{P} 3$ (MS + 2ppm BAP) & 1,42 \\
\hline $\mathrm{P} 4(\mathrm{MS}+3 \mathrm{ppm} \mathrm{BAP})$ & 0,79 \\
\hline $\mathrm{P} 5$ (MS + 4ppm BAP) & 0,76 \\
\hline P6 (MS + 5ppm BAP) & 0,82 \\
\hline
\end{tabular}

Keterangan : Angka yang diikuti huruf yang sama pada satu kolom menunjukkan angka yang berbeda tidak nyata berdasarkan uji DMRT (Duncan's Multiple Range Test)

Note: The numbers followed by same alphabet show insignificant difference based on DMRT (Duncan's Multiple Range Test)

Perlakuan P1 (MS + 0 ppm BAP) menjadi perlakuan dengan nilai terendah dikarenakan tidak muncul tunas hingga akhir pengamatan, diduga karena didalam media kultur jaringan pada P1 tidak mengandung zat pengatur tumbuh, dan juga hormon endogen dalam eksplan belum mampu menumbuhkan tunas pada eksplan. Hal ini didukung oleh Fathurrahman et al. (2012) yang menyatakan bahwa tanpa pemberian zat pengatur tumbuh eksogen (BAP) kedalam media, hormon endogen yang tersedia belum mampu mendorong pembelahan sel dan pembesaran sel sehingga pembentukan tunas tidak bisa terbetuk secara optimal seperti yang diharapkan.

\section{KESIMPULAN}

Berdasarkan hasil hasil dan pembahasan dapat disimpulkan sebagai berikut :

a. Penambahan variasi konsentrasi BAP dalam media memberikan pengaruh sangat nyata terhadap kedinian tunas, eksplan bertunas, jumlah tunas, dan tinggi tunas.

b. Penambahan BAP 2 ppm merupakan konsentrasi terbaik untuk induksi tunas tembakau Kasturi 2 dengan kedinian bertunas 12,17 hari setelah inokulasi, eksplan bertunas $100 \%$, rerata jumlah tunas 47,50 buah per eksplan dan rerata tinggi tunas $10,42 \mathrm{~mm}$.

\section{DAFTAR PUSATAKA}

Balai Penelitian Tanaman Pemanis dan E Serat. (2014). Tembakau Kasturi. Kementerian Pertanian. http:// balittas.litbang.pertanian.go.id/index .php/id/produk/varietasunggul/tembakau/257-kasturi

Direktorat Jenderal Perkebunan. (2017). Etatistik Perkebunan Indonesia 2015 - 2017: Tembakau (Tobacco). Kementerian Pertanian Indonesia. 
Erawati, D. N., Fisdiana, U., \& Humaida, 咱 S. (2018). Peran Benzyl Amino Purine Pada Induksi Tunas Kultur Tembakau White Burley. Jurnal Ilmiah Inovasi, 17(3), 127-131. https://doi.org/10.25047/jii.v17i3.55 3

Fahmi, Z. I. (2014). Kajian Pengaruh 期 Auksin Terhadap Perkecambahan Benih dan Pertumbuhan Tanaman. Balai Besar Perbenihan dan Proteksi Tanaman Perkebunan Surabaya.

Fathurrahman, Rosmawati, T., Syaifuddin, 琶 A., \& Gunawan, S. (2012). Multiplikasi Tunas Pucuk Tomat (Lycopersicum esculentum Mill) dengan Menggunakan Benzyl Amino Purine (BAP) dan Naphtalene Acetic Acid (BAP) secara In Vitro. Jurnal Agroteknologi, 1(1), 1-12. https://doi.org/10.31219/osf.io/j75gd

Nisak, K., Nurhidayati, T., \& Purwani, K. 钢 I. (2012). Pengaruh Kombinasi Konsentrasi ZPT NAA dan BAP pada Kultur Jaringan Tembakau Nicotiana tabacum var. Prancak 95. Jurnal Sains Dan Seni Pomits, 1(1), $1-6$.

Sarala, K., \& Ravisankar, H. (2013). Explant Autonomy in Indian Tobacco Cultivars Under in Vitro. Access International Journal of Agricultural Sciences, 1(3), 30-36.

Sultan, I. N., A, M., Yousafzai, A., Sattar, 的 F. A., Ahmmad, F., Ibrahim, S. M., Hassanullah, M., \& Arif, B. (2011). The Effects of Different Concentrations and Combinations of Growth Regulators on the Callus Formation of Potato ( Solanum tubrosum ) Explants. Current Research Journal of Biological Sciences, 3(5), 499-503.
Tjitrosoepomo, G. (1985). Morfologi 到 Tumbuhan. Gadjah Mada University Press.

Zulkarnain. (2011). Kultur Jaringan 琶 Tanaman: Solusi Perbanyakan Tanaman Budi Daya. Bumi Aksara. 